\title{
THE IMPACT OF ORGANISATIONAL CULTURE ON THE ADAPTATION OF NEWLY EMPLOYED NURSES TO THE WORK ENVIRONMENT
}

\author{
Prof LB Khoza \\ DLitt et Phil \\ Associate Professor, University of Venda for Science and Technology, Thohoyandou \\ Corresponding author: bkhoza@univen.ac.za
}

Keywords: organisational culture; adaptation; adjustment; newly employed nurses; socialisation process

\begin{abstract}
Usually newly employed nurses find adjusting to a work setting a challenging experience. Their successful adaptation to their work situation is greatly influenced by the socialisation process inherent in the organisational culture. The newly employed nurse often finds that the norms are unclear, confusing and restrictive. The purpose of the study was to examine the impact of organisational culture on the adaptation of newly employed nurses to the work environment. A descriptive quantitative survey was employed to explore the constructs of organisational culture that have a positive or a negative impact on the adaptation of newly employed nurses to the work setting. Constructs such as conflict resolution, employee participation, human resource orientation, goal clarity, identification with the organisation, locus of control and management style were examined. Participants expressed their views as to what constructs of organisational culture had a positive or a negative impact on their adjustment to the work settings. For the culture to serve its function it must be perceived as correct and valid and if it is perceived that way, it automatically follows that it must be taught to newcomers.
\end{abstract}

\section{OPSOMMING}

Gewoonlik is die aanpassing by 'n nuwe werksomgewing vir pasaangestelde verpleegkundiges ' $n$ groot uitdaging. Hulle aanpassing by hulle nuwe werksituasie word grootliks beïnvloed deur die sosialiseringsproses inherent in die organisatoriese kultuur. Die pasaangestelde verpleegkundige vind dikwels dat die norme onduidelik, verwarrend en beperkend is. Die doel van hierdie studie was om die impak van die organisatoriese kultuur op die aanpassing in die werksomgewing van pasaangestelde verpleegkundiges te ondersoek. 'n Beskrywende, kwantitatiewe ondersoek is gebruik om die verskillende aspekte van die organisatoriese kultuur wat 'n positiewe en/of 'n negatiewe impak op die aanpassing in die werksomgewing van pasaangestelde verpleegkundiges het, te verken. Aspekte soos konflikoplossing, werknemerdeelname, menslike hulpbronoriëntasie, duidelikheid van doelstellings, identifikasie met die onderneming, die setel van beheer, en die bestuurstyl is ondersoek. Deelnemers het hulle menings uitgespreek oor watter aspekte van die organisatoriese kultuur 'n positiewe of 'n negatiewe impak op hulle aanpassing by die werksomgewing het. Ten einde kultuur effektief te laat funksioneer moet dit as korrek en geldig waargeneem word en indien dit wel die geval is, volg dit vanselfsprekend dat dit by pasaangestelde verpleegkundiges tuisgebring moet word. 


\section{INTRODUCTION AND BACKGROUND OF THE STUDY}

One element of an organisational system is the organisational culture. The organisational culture $(\mathrm{OC})$ refers to a system of shared meanings including the language, dress, patterns of behaviour, value systems, feelings, attitudes, interactions, and group norms of the members (Harvey \& Brown, 1996:11). OC can be analysed at several different levels, such as the constructed environment of the organisation's technology, space and time, visible and audible behaviour, patterns, employee orientation materials, mission statement and philosophy, and it can also be analysed in terms of why members behave the way they do (Harvey \& Brown, 1996:69; Van Dyk, 1997:238). An organisation itself has an invisible quality, a certain style and character of doing things; for instance, one may question how nurses in a particular hospital setting dress or wear their hair. Are there flexi-working hours? What jargon is used? This implies that there is no basic culture that works best for all organisations.

Usually newly employed nurses are influenced by the OC. The newly employed nurse often finds that the norms are unclear, confusing and restrictive. More often than not the OC expects newly employed nurses to do a full day's labour every working day, to be productive, not to be unnecessarily absent, not to make mistakes, to be loyal to the employer, to work overtime if necessary, to render excellent service, to strive for the goals of the organisation, namely quality patient care (Louis, 1980:226-230). A new member may choose to conform to the $\mathrm{OC}$, resulting in uniformity that may result in stagnation, non-responsiveness and a loss of creativeness. At the other extreme the new member may choose to rebel, to reject all values, or to leave the organisation altogether (Van Dyk, 1997:59).

In learning the culture, newly employed nurses develop a definition of the situation, interpreting everyday events in the setting, and comparing their findings with those prescribed by the OC. Experiences during this period of encounter are critical in shaping the individual's longterm orientation to the organisation. There is evidence to suggest that different patterns of socialisation lead to different forms of newly employed nurses' adjustment and adaptation to organisations. New employees' experiences of organisational reality at different stages in socialisation procedure may result in such outcomes as satisfaction and feelings of personal worth, commitment or otherwise, burnout, disillusionment, aggressiveness or turnover (Jones, 1996:262-279; Van Ess Coeling, 1990:26-28).

This study findings could bring awareness to health service managers that expecting new employees to adapt instantly to imposed values of OC without careful assessment of new employees' values which they may bring in the organisation may result into serious confrontation

\section{PROBLEM STATEMENT}

Usually newly employed nurses find adjusting to a work setting a challenging experience. Their successful adjustment and adaptation to their work situation is greatly influenced by socialisation processes inherent in the OC.

There might be clashes of values between the newly employed nurse and the service managers; for instance, newly employed nurses may prefer flexible working hours, a specific form of placement in the clinical unit, and job design that are contrary to the prescribed norms and values of the organisation. Such a situation may affect their adjustment and ability to adapt to OC. Voluntary turnover may increase and this takes place in spite of growing corporate attention to the orientation and retention activities exercised by various organisations (Harvey \& Brown, 1996:237-241).

Several forms of surprise often arise during the encounter stage and require adaptation on the part of the newly employed nurse. Both pleasant and unpleasant surprises require adaptation. Surprise may be positive, that is, "OC does not contradict my values; I am well cared for in this unit; I receive more fringe benefits than I expected; my manager is a caring person"; or negative, "I cannot work night duty; I still need extensive orientation to OC; the atmosphere is tense; the job is unfamiliar; the unit culture is conflicting with mine; there is no recognition of one's needs". In order to perform adequately in the newly employed nurse professionals' role, they need ability, motivation, and an understanding of what others expect. All these aspects constitute an OC. In view of these adaptation problems experienced by new employees, this research was aimed at 
identifying the elements of OC that have a positive or negative impact on the adaptation of newly employed nurses to the work environment.

\section{PURPOSE OF THE STUDY}

The purpose of the study was to examine the impact of $\mathrm{OC}$ on the adaptation of newly employed nurses to the work environment of the health care services of the Limpopo Province. The study identified and described those elements of $\mathrm{OC}$ that might have a positive or negative impact on the adaptation abilities of newly employed nurses and suggested recommendations to enhance the adaptation of new employees to the work environment.

The following constructs of $\mathrm{OC}$ were explored and those that seemed to be supported by the newly employed nurses were regarded in the study to be essential to enhance their adaptation to the work environment (Van der Post, De Koning \& Smit, 1997:147-169):

- conflict resolution - to determine how the health services encourage newly employed nurses to air conflicts and criticisms openly;

- employee participation - to examine the extent to which newly employed nurses participate in the decision-making processes of the organisation;

- human resource orientation - to examine the organisation's level of regard for its newly employed nurses;

- goal clarity - to examine the degree to which the organisation creates clear objectives and performance expectations for newly employed nurses;

- identification with the organisation by newly employed nurses;

- locus of authority - to examine the degree of authority, freedom and independence that individual newly employed nurses have in their jobs; and

- management style - to examine the degree to which managers provide clear communication, assistance and support to newly employed nurses.

\section{QUESTIONS OF THE STUDY}

The overall research question that guided this research was: "What are the constructs of OC that have a positive or negative impact on the adaptation of newly employed nurses to the work environment?"

Answers to the following questions were sought:

- What constructs of $\mathrm{OC}$ have a positive impact on the adaptation of newly employed nurses to the work environment?

- What constructs of OC have a negative impact on the adaptation of newly employed nurses to the work environment?

\section{DEFINITION OF TERMS}

Organisational culture: Organisational culture in this study refers to those constructs that have been perceived by newly employed nurses to be having some positive or negative impact on their adaptation to work environment.

Newly employed nurses: Newly employed nurses in this study refers to enrolled and professional registered nurses who had been employed within a period of less than 18 months in the organisation.

\section{RESEARCH METHODOLOGY}

\section{Study Design}

A descriptive survey was employed to provide insight into the impact of $\mathrm{OC}$ on the adaptation abilities of newly employed nurses. Seaman (1987:182) considers a descriptive study as a 'factor searching study', sophisticated and difficult. It may lead to new ways of thinking about important $\mathrm{OC}$ problems, and may possibly lead to change in $O C$ to increase the organisation's effectiveness. A descriptive survey provides an accurate portrayal of the characteristics of a particular event, for the purposes of discovering new meanings, describing what exists and determining the frequency with which something occurs, and categorising information (Burns \& Grove, 2001:795).

\section{RESEARCH POPULATION}

A population is defined as the totality of all subjects that conform to a set of specifications (Polit \& Hungler, 1995:43). The population in this research study comprised all newly employed nurses within a period of 
less than 18 months working in one particular hospital in Limpopo Province of South Africa. The population included all nursing categories, such as enrolled nurses and professional registered nurses. A list comprising of 54 newly employed nurses as defined in the study was obtained from the nurse manager of human resources. Furthermore, the whereabouts of these newly employed nurses were identified using the allocation rosters of various units.

\section{SAMPLING METHOD}

No sampling procedures were applied to the participants because the number of newly employed nurses was considered to be relatively small, therefore enabling the target population as a whole to participate in this study. Forty-nine out of fifty-four newly employed nurses participated in the research. Five could not be traced because some were on vacation leave while others were working altered shifts.

\section{Data Collection}

The researcher used a self-reporting questionnaire as the method of data collection. The questionnaire was developed after perusal of literature addressing OC. Tzeng, Ketefian and Redman (2002:79-84) studied the relationship of nurses'assessment of OC, job satisfaction and patient satisfaction with nursing care whereas, Van der Post et al. (1997:164-179) have developed an instrument to measure $\mathrm{OC}$.

A questionnaire comprised of 46 Likert-type statements was administered to the participants. The participants were requested to indicate their response by putting a tick in the space beside the category which most accurately fits the extent to which the newly employed nurse agrees or disagrees with the statement that describes the organisation in which he/she works. The following key was used to guide the participants:

$$
\begin{aligned}
& S A=\text { Strongly agree } \\
& A=\text { Agree } \\
& U=\text { Uncertain } \\
& D=\text { Disagree } \\
& S D=\text { Strongly disagree }
\end{aligned}
$$

The questionnaires were not mailed, but delivered by the researcher for completion on the appointed dates. Participants working during the night were also followed up on. The advantage of this method was to maximise the response rate and it was cost effective as there was no postage involved.

\section{VALIDITY AND RELIABILITY}

Reliability can be defined as the degree of consistency with which an instrument measures the attribute it is designed to measure whereas; validity can be defined as the degree in which an instrument measures what it is intended to measure (Polit \& Hungler, 1995:651-656). In this study reliability and validity were ensured by formulating questions as simply as possible to reduce ambiguities, the questionnaire was developed after intense literature review, clear instructions were given to respondents verbally by the researcher and pre-testing of the instrument was done with five newly employed nurses who were excluded in the study sample.

\section{SCOPE AND LIMITATIONS OF THE STUDY}

The study examined the impact of OC on the adaptation of newly employed nurses to the work environment in one particular health care setting. It might not be possible to generalise the findings of the study to the entire health service of Limpopo Province, South Africa.

\section{ETHICAL CONSIDERATIONS}

In observance of the ethical constraints underlying the undertaking of a research project, the following aspects were considered:

- A letter requesting permission to conduct the study was addressed to the Head of Department of Health and Welfare, Limpopo Province.

- A covering letter to complement the researcher's purpose of the research was issued together with the questionnaires requesting cooperation of newly employed nurses. Anonymity and confidentiality of the individuals and the hospital were guaranteed. Names were not requested from the newly employed nurses.

- Participation in research remained voluntary and depended on the willingness of each participant. Newly employed nurses were given a questionnaire in an unsealed envelope to be sealed after completion. Cooperation to return uncompleted questionnaires was also requested. 
- Co-operation was requested from the nurse managers of the hospital concerning the researcher's visits to the wards where newly employed nurses were working. The consultations with the newly employed nurses took place during the day and at night for the participants who were taking night shifts.

- The participants' right to maintain self-respect and dignity were observed through protection from physical and psychological risks during the study. Nobody could benefit from participation nor be harmed by refusal to participate in this study.

\section{DATA ANALYSIS}

Data were encoded and computerised by using the Statistical Package for Social Sciences (SPSS) by a statistician from the University of the North. Descriptive statistics of frequencies and percentages were used to describe data regarding the views of the participants. Tables were constructed of the responses to the questionnaire and are generally more useful for summarising most of the data, as they can be more easily understood and interpreted by the reader (Knapp, 1998:258).

The summation of responses was done where 'strongly agree' and 'agree' were summed as 'agree', and 'disagree' and 'strongly disagree' were summed as 'disagree'.

Depending on the description of the statement and the participants' perceptions, both the 'agree' and the 'disagree' could indicate a positive or negative impact of $\mathrm{OC}$ on the adaptation of newly employed nurses to the work environment. Responses of $50 \%$ and more implied that the statement had an impact on the adaptation of newly employed nurses. Those statements that were ticked 'uncertain' were not considered as having an impact on this study.

\section{FINDINGS}

The data were categorised to describe specific constructs of OC as indicated in the purpose of the study. The numbering of statements in the tables was consistent with the numbers appearing in the main table that was not included in the article.
Table 1 reveals that newly employed nurses viewed the organisation as not having high regard for them; not treating newly employed nurses as if they are a valued resource; not really valuing its employees; and treating employees as though they have nothing to contribute towards the organisation's performance. The findings could imply that the newly employed nurses might have difficulty adapting to the work environment. The study by Tepeci and Bartlett (2002) revealed that satisfied employees were more likely to stay with the organisation and contribute to the organisation's bottom line, whereas dissatisfied employees were likely to deliver low quality service. This study therefore recommends that research be conducted to assess the quality of care given to patients in the hospital.

Owen (2001:612) asserts that within OC literature, there is an often implicit assumption that the existing community of practice or culture is appropriate and desired and that enculturation is needed for new employees to understand existing ways of work.

Table 2 reveals that newly employed nurses strove to some extent to identify themselves with the organisation. This is supported by the fact that $60 \%$ of newly employed nurses agreed that they were committed to making the organisation successful. New employees $(59 \%)$ indicated that they did not experience a sense of belonging to the organisation, and $51 \%$ indicated that the organisation did not encourage its employees to identify with each other and the organisation. Fiftyeight percent of the participants disagreed with the statement that employees in the organisation had confidence and trust in each other.

Van Ess Coeling (1990:28) did a research follow up with new nurse employees in the USA. 'Using work group culture knowledge to adjust to working life' was her theme. The new nurse employees were quick to identify whether the priority of their work group was giving physical and psychological care. One nurse shared how a strong focus on organisational efficiency motivated her to change her behaviour so that she could fit in with the group. She explained, "I was told to be organised when I started here. This changed me. I am not an organised person, so I have become more organised. I am willing to become more organised because I enjoy working here" (Van Ess Coeling, 1990:28). 
Table 1: Human resource orientation constructs as perceived by newly employed nurses $(n=49)$

\begin{tabular}{|l|l|l|l|}
\hline NO & STATEMENT & AGREE \% & DISAGREE\% \\
\hline 1 & This organisation has high regard for its employees & 35 & 56 \\
\hline 6 & This organisation does not treat employees as if they are valued resources & 55 & 36 \\
\hline 13 & This organisation does not really value its employees & 54 & 33 \\
\hline 24 & $\begin{array}{l}\text { This organisation treats employees as though they have nothing to contribute } \\
\text { towards the organisation's performance }\end{array}$ & 51 & 33 \\
\hline 29 & $\begin{array}{l}\text { This organisation views its employees as important contributors to the } \\
\text { organisation's success }\end{array}$ & 47 & 32 \\
\hline
\end{tabular}

Table 2: Identification with the organisation constructs as perceived by newly employed nurses $(n=49)$

\begin{tabular}{|l|l|l|l|}
\hline NO & STATEMENT & AGREE\% & DISAGREE\% \\
\hline 4 & $\begin{array}{l}\text { In this organisation, employees are committed to making the organisation } \\
\text { successful }\end{array}$ & 60 & 28 \\
\hline 12 & Employees in this organisation have confidence and trust in each other & 38 & 58 \\
\hline 32 & Employees do not experience a sense of belonging to this organisation & 59 & 39 \\
\hline 40 & $\begin{array}{l}\text { This organisation does not encourage its employees to identify with each } \\
\text { other and the organisation }\end{array}$ & 34 & 51 \\
\hline
\end{tabular}

Table 3: Management style constructs as perceived by newly employed nurses $(n=49)$

\begin{tabular}{|l|l|l|l|}
\hline NO & STATEMENT & AGREE\% & DISAGREE\% \\
\hline 9 & $\begin{array}{l}\text { Managers in this organisation provide clear communication, and support to } \\
\text { their subordinates }\end{array}$ & 42 & 54 \\
\hline 16 & This organisation listens to the views of the employees & 40 & 52 \\
\hline 21 & In this organisation seniors are helpful and supportive when needed & 55 & 37 \\
\hline 22 & $\begin{array}{l}\text { In this organisation employees are empowered to make appropriate } \\
\text { decisions on their own }\end{array}$ & 34 & 38 \\
\hline 31 & $\begin{array}{l}\text { In this organisation there is a low level of trust in and openness with the } \\
\text { managers }\end{array}$ & 56 & 56 \\
\hline 33 & $\begin{array}{l}\text { In this organisation communication flows freely and accurately throughout } \\
\text { the organisation }\end{array}$ & 40 & 40 \\
\hline 34 & $\begin{array}{l}\text { Employees in this organisation cannot rely on management support when } \\
\text { needed }\end{array}$ & 55 & 47 \\
\hline 37 & This organisation has a participative management style & 44 & 48 \\
\hline
\end{tabular}

This was contrary to several nurses who planned to leave their units indicating that seniors were not helping them enough to enhance their adaptation. Seniors would use an indirect manner of criticism and they would talk behind their backs, or the newly employed nurses just sensed that people were disapproving (Van Ess Coeling, 1990:28).

The role of identification with the organisation by new employees is crucial and often neglected. It needs to be realised that to practise the basic requirements of culture independently needs a substantial amount of on-the-job support for months after orientation. Louis (1980:20) indicates that the individual's adaptation to the organisation occurs with the passage from newcomer to insider. New employees become insiders when and as they are given information, encouraged to represent the organisation and are sought out for advice 
and counsel by others. By so doing new employees will express less or no stress at all and this enhances their adaptation to the work environment.

Table 3 reveals that $55 \%$ of newly employed nurses agreed that seniors were helpful and supportive when required. Contrary to this, more than $50 \%$ of new employees indicated that they could not rely on management support when needed; there was a low level of trust in and openness with the managers and they disagreed that in the organisation communication flows freely. In an organisation continuous meaningful dialogue is vital. Dialogue engages each individual with others in a direct and effective way. When practised well, it brings healthy interpersonal relationships among managers and subordinates.

Van Dyk (1997:251) expresses that management is both a cause of and a part of organisational characteristics. The existing culture of a given organisation reflects past and present managerial planning, organising, leading, and controlling activities. A healthy culture involving all employees may be enhanced if managers interact with other managers and with non-managers and individual and group settings to establish plans, policies, procedures, rules, job descriptions, lines of authority and communication.

Table 4 reveals that $57 \%$ of newly employed nurses felt that they have freedom and independence to do their jobs effectively, and that they are encouraged to use their own initiative in doing their jobs. Despite these positive factors mentioned, $63 \%$ of new employees felt that authority to make decisions is only in the hands of seniors and decisions are to be transferred upwards all the time, as indicated by $57 \%$ of the participants.

The degree of freedom and independence that new employees could feel they have without authority to make decisions in their jobs is questionable. It is generally expected that freedom, independence and authority should be given to all employees to ensure quality delivery.

Table 5 reveals that newly employed nurses agreed that they were not encouraged to reveal any differences of opinion which they might have with their seniors; and that the organisation tends to deal with differences of opinion by ignoring them; and people in the organisa- tion are not interested in hearing views that do not agree with their own. Furthermore, $57 \%$ of new employees disagreed that there was an air of trust and openness in the organisation. This may imply that newly employed nurses are not satisfied with the manner in which conflicts are managed. Adversely this could interfere with the newly employed nurses' adaptation to the clinical setting.

Table 6 indicates that newly employed nurses felt that they were not adequately involved in various aspects of decision-making such as that the organisation does not allow them to participate in decision-making; they have little say in their own goals and they felt creativity is definitely not encouraged in the organisation. Employee participation is fundamental to the survival of the organisation. Owen (2001:598) indicates that in an organisation employees should develop the skills of conscious inquiry, including behaviour such as:

- being able to ask relevant and thought-provoking questions;

- sharing observations;

- seeking alternative perspectives;

- assertively challenging a particular opinion;

- seeking clarification; and

- sharing information through processes of consulting and collaborating.

Managers who allow this to take place in an organisation have little or nothing to worry about in terms of staff turnover, quality care and quality performance by employees. Lack of participation in the work place affects job satisfaction. The study done by Tepeci and Bartlett (2002) indicated that dissatisfied employees were likely to deliver low quality service resulting in clients'/patients' dissatisfaction.

Dwyer, Richard and Chadwick (2003:79-84) describe the clan culture type based on the development of human resources and employee participation in decisionmaking. The emphasis is placed on teamwork, cohesiveness, and generally a friendly place in which to work. Such an environment is likely to enhance adaptation and increase the sense of belonging to the organisation in newly employed nurses.

It is pleasing to realise that the organisational goals were perceived to be clear to newly employed nurses. Table 7 reveals that above $60 \%$ of newly employed 
Table 4: Locus of control constructs as perceived by newly employed nurses $(n=49)$

\begin{tabular}{|c|c|c|c|}
\hline NO & STATEMENT & AGREE\% & DISAGREE\% \\
\hline 2 & Employees have freedom and independence to do their jobs effectively & 57 & 33 \\
\hline 3 & $\begin{array}{l}\text { In this organisation authority to make decisions is only in the hands of } \\
\text { seniors }\end{array}$ & 63 & 36 \\
\hline 5 & In this organisation decisions are to be referred upwards all the time & 57 & 37 \\
\hline 38 & $\begin{array}{l}\text { Employees in this organisation are encouraged to use their own initiative in } \\
\text { doing their jobs }\end{array}$ & 54 & 35 \\
\hline 42 & $\begin{array}{l}\text { Employees have to double check first with their managers before getting on } \\
\text { with their jobs }\end{array}$ & 35 & 50 \\
\hline
\end{tabular}

Table 5: Conflict resolution constructs as perceived by newly employed nurses $(n=49)$

\begin{tabular}{|l|l|l|l|}
\hline NO & STATEMENT & AGREE\% & DISAGREE\% \\
\hline 8 & $\begin{array}{l}\text { New employees are not encouraged to reveal any differences of opinion } \\
\text { which they may have with their seniors }\end{array}$ & 51 & 33 \\
\hline 11 & Differing views are encouraged in this organisation & 47 & 30 \\
\hline 23 & $\begin{array}{l}\text { This organisation tends to deal with differences of opinion by ignoring } \\
\text { them }\end{array}$ & 51 & 31 \\
\hline 28 & $\begin{array}{l}\text { The people in the organisation are not interested in hearing views that do } \\
\text { not agree with their own }\end{array}$ & 50 & 31 \\
\hline 35 & There is an air of trust and openness in this organisation & 35 & 57 \\
\hline 41 & Differences of opinions are welcomed in this organisation & 43 & 43 \\
\hline
\end{tabular}

Table 6: Employee participation constructs as perceived by newly employed nurses ( $n=49$ )

\begin{tabular}{|l|l|l|l|}
\hline NO & STATEMENT & AGREE\% & DISAGREE\% \\
\hline 14 & $\begin{array}{l}\text { Employees in this organisation are genuinely encouraged to participate in } \\
\text { broad organisational policy matters }\end{array}$ & 39 & 47 \\
\hline 20 & $\begin{array}{l}\text { This organisation does not allow employees to participate in the decision- } \\
\text { making process }\end{array}$ & 50 & 40 \\
\hline 25 & Employees in this organisation have very little say in their own work goals & 55 & 45 \\
\hline 27 & $\begin{array}{l}\text { Employees in this organisation have a say in the organisation's long-term } \\
\text { success }\end{array}$ & 39 & 35 \\
\hline 45 & Creativity is definitely not encouraged in this organisation & 40 & 52 \\
\hline
\end{tabular}

Table 7: Goal clarity constructs as perceived by newly employed nurses $(n=49)$

\begin{tabular}{|l|l|l|l|}
\hline NO & STATEMENT & AGREE\% & DISAGREE\% \\
\hline 7 & $\begin{array}{l}\text { In this organisation there are too many rules, regulations, and standard } \\
\text { procedures }\end{array}$ & 63 & 28 \\
\hline 15 & $\begin{array}{l}\text { Employees in this organisation do not understand what contribution is } \\
\text { expected from them }\end{array}$ & 31 & 59 \\
\hline 18 & $\begin{array}{l}\text { Employees in this organisation do not know what is expected of them in } \\
\text { their jobs }\end{array}$ & 42 & 56 \\
\hline 39 & $\begin{array}{l}\text { Employees in this organisation understand the objective of the } \\
\text { organisation }\end{array}$ & 65 & 28 \\
\hline 44 & In this organisation goals are not clearly defined & 46 & 41 \\
\hline
\end{tabular}


nurses agreed that the organisation had too many rules, regulations and standard procedures, and that employees understood the objectives of the organisation. This is supported by the fact that $56 \%$ and more of the new employees disagreed with the statements such as that employees in the organisation do not know what is expected of them in their jobs, and that they do not understand what contribution is expected of them.

Harvey and Brown (1996:323) state that goals give direction to an individual's life and provide purpose and direction to organisation. Goals include standards for behaviour and performance and are intended to increase efficiency and effectiveness by specifying the desired outcomes towards which individuals, teams and the organisation should work. In a hospital setting the goal is the provision of quality patient care by all health workers. Guidelines in the form of policies, procedure manuals, protocols and learning programmes are kept in place to accomplish the desired outcome.

Out of seven statements, $55 \%$ and above of newly employed nurses agreed to only two aspects, that the organisation consistently makes employees aware of how they are expected to behave at work and that they have a clear understanding of what its values and philosophy are in the organisation. However, $51 \%$ of newly employed nurses disagreed that in the organisation there is clear link between reward and performance.

The findings may imply that managers in the organisation do interact with subordinates to establish policies, procedures, rules and standards. All of these interactions may create an $\mathrm{OC}$ that will have an impact on new employees' adaptation to the organisation. Managers may expect the new nurse to conform and be compliant to the OC. Newly employed nurses may be socialised in the same direction when it comes to standards, beliefs, values and expectations, whereas individuals should identify themselves to such an extent with the beliefs and values of the organisation that their values and beliefs correspond to those of the organisation.

\section{CONCLUSIONS AND RECOMMENDA- TIONS}

\section{Human resource orientation and locus of control}

Because culture serves the function of stabilising the external and internal environment of the organisation, it must be taught to new members. For culture to serve its function it must be perceived as correct and valid and if it is perceived that way, it automatically follows that it must be taught to newcomers. However, it should not be overlooked that new members bring new ideas and produce culture change no matter what the level of their entrance into the organisation. Owen (2001:598) indicates that employees, new or old, should develop the skills of conscious inquiry, being able to ask relevant and thought-provoking questions and seeking clarification, consulting and collaborating. It is through sustained interaction that individuals come to share

Table 8: Culture management constructs as perceived by newly employed nurses $(n=49)$

\begin{tabular}{|l|l|l|l|}
\hline NO & STATEMENT & AGREE\% & DISAGREE\% \\
\hline 10 & $\begin{array}{l}\text { In this organisation there is an informal atmosphere which helps } \\
\text { employees to get the job done }\end{array}$ & 39 \\
\hline 17 & $\begin{array}{l}\text { There is nothing holding this organisation together and binding its } \\
\text { members to one another }\end{array}$ & 39 & 35 \\
\hline 19 & $\begin{array}{l}\text { This organisation has strong values which are widely shared by its } \\
\text { members }\end{array}$ & 46 & 19 \\
\hline 30 & $\begin{array}{l}\text { Managers in this organisation seldom do anything which shows } \\
\text { employees what is important for the organisation's work methods } \\
\text { This organisation consistently makes employees aware of how they are }\end{array}$ & 66 & 37 \\
\hline 36 & $\begin{array}{l}\text { Employees in this organisation have a clear understanding of what its } \\
\text { values and philosophy are }\end{array}$ & 55 & 32 \\
\hline 43 & \begin{tabular}{l} 
In this organisation there is clear link between reward and performance \\
\hline
\end{tabular} & 32 \\
\hline
\end{tabular}


common ways of thinking and expressing ideas.

\section{Goal clarity}

Health care managers must be able to show newly employed members how the organisation's goals are linked, and how they support the integrated delivery system. Employee involvement, empowerment and buyin management are new techniques for unleashing human potential in organisations. The main idea is to delegate power and decision-making to lower levels, and by using concepts like shared vision of the future. The findings of this study revealed that decision-making was in the hands of managers. Engaging all employees in decision-making, would assist them to develop in themselves a sense of pride, self-respect and responsibility. Management is responsible for creating a supportive climate and removing barriers (Harvey \& Brown, 1997:239).

Providing a vision for the nursing service is not enough. Nurse managers should also provide structures and processes so that the vision can be sustained. Structural elements may include adequate human resources, equipment, orientation programmes and learning programmes for newly employed nurses. A leader manager who has a vision only, and does not support it with structure, is merely wishing for change. Hoping dreams will come true, without working towards a goal, is unrealistic. Adequate structures and processes are likely to inspire new members to strive for the success of the organisation.

\section{Conflict resolution and identification with the organisation}

Newly employed nurses need to be satisfied with their co-workers. In a hospital setting, there is emphasis on a patient-focused care approach for the delivery of health services. This approach involves the utilisation of a work group or team. It is critical that hospital managers seek to develop a healthy climate of mutual trust and respect between and among co-workers. Problems and conflicts between co-workers should be addressed quickly and resolutions should be clearly communicated to the newly employed nurses.
Managers should periodically ascertain how satisfied new employees are with working conditions, pay and vacation leaves. Rarely, however, are surveys of the new employees' ability to adapt to the work place, satisfaction with co-workers and the clinical placement undertaken. This study therefore recommends that further research be conducted.

Nurse managers are role models for their new employees especially since they are the primary educators in terms of gaining organisational commitment from their subordinates.

The active nurse manager not only demonstrates a commitment to organisational goals and values, but also engenders respect and loyalty in staff members. The most ineffective manager is the individual who remains hidden in the office all day and comes out to issue directives and other proclamations (Bolon, 1997:339).

\section{REFERENCES}

BOLON, DS 1997: Behavior among hospital employees. Hospital and Health Services Administration, 43(3):339-364.

BURNS, N \& GROVE, SK 2001: The practice of nursing research: conduct, critique and utilization. Philadelphia: WB Saunders.

DWYER, S; RICHARD, OC \& CHADWICK, K 2003: Gender diversity in management and firm performance: the influence of growth orientation and organizational culture. Journal of Business Research, 56(12):1009-1019.

HARVEY, DF \& BROWN, DR 1996: An experiential approach to Organisation Development. London: Prentice-Hall.

JONES, GR 1996: Socialisation tactics, self-efficacy and newcomers' adjustment to organisations. Academy of Management Journal, 29(2):262-279.

KNAPP, TR 1998: Quantitative nursing research. London: Sage. LOUIS, ME 1980: Surprise and sense making: What newcomers experience in entering unfamiliar organisational settings. Administrative Science Quarterly, 25(2):226-251.

OWEN, CA 2001: The role of organisational context in mediating workplace learning and performance. Computers in Human Behaviour, 17(5-6):597-614.

POLIT, DF \& HUNGLER, BP 1995: Nursing research, principles and methods; $4^{\text {th }}$ edition. Philadelphia: JB Lippincott.

SEAMAN, HC 1987: Research methods: Principles, practice and theory for nursing. Norwalk: Appleton \& Lange.

TEPECI, M \& BARTLETT, AL 2002: The hospitality industry culture profile: A measure of individual values, organizational cul- 
ture, and person-organization fit as predictors of job satisfaction and behavioral intentions. International Journal of Hospitality Management, 21(2):151-170.

TZENG, HM; KETEFIAN, S \& REDMAN RW 2002: Relationship of nurses' assessment of organizational culture, job satisfaction, and patient satisfaction with nursing care. International Journal of Nursing Studies, 39(1):79-84.

VAN DER POST, WZ; DE KONING, TJ \& SMIT, EM 1997: An instrument to measure organizational culture. Stellenbosch: University of Stellenbosch.

VAN ESS COELING, H 1990: Organizational culture: helping new graduates to adjust. Nurse Educator, 15(2):26-28.

VAN DYK, PS 1997: Module 2: Organisational behaviour and renewal. Pretoria: UNISA.

\section{South African Conference on Positive Psychology:} Individual, Social and Work Wellness

[Incorporating the 3rd South African Work Wellness Conference]

The Psychofortology Research 2006 in Potchefstroom, South Programme, the WorkWell Africa. Pre-conference workResearch Unit, and the Division shops will be presented on 4 April for Health-Promoting Schools at 2006.

North-West University are The Aim of the conference is to pleased to announce that they will provide an update on theory, be co-hosting the first positive measurement and application in psychology conference in Africa.

The South African Conference on Positive Psychology 2006: Individual, Social and Work Wellness will be held on 5-7 April in general, and in particular as pertains to individual, social and work wellness in a multicultura context. The conference will pro- vide opportunities for discussion, debate, promotion of knowledge and development of skills, and future networking.

The call for papers, invitation to register and further information is available at:

http://sappc.puk.ac.za, or from Tel: +27 (018) 2991397

(Melanie Matthews),

Email: sapc2006@puk.ac.za.

WorkWell

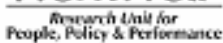

